\title{
DETERMINAN KEBAHAGIAAN DI INDONESIA
}

\author{
Theresia Puji Rahayu \\ Fakultas Ekonomika dan Bisnis, Unika Atma Jaya Jakarta \\ theresiarh@gmail.com
}

\begin{abstract}
ABTRACT
The research objective is to analyse the determinants of happiness in Indonesia. Using cross-section data from Indonesia Family Life Survey (IFLS) wave 4, 2007, this study takes 17.650 observations which estimated using Oprobit model. The Oprobit model was chosen because of ordinaled response variable and the normal assumption in error distribution. The result shows that happiness in Indonesia positively affected by income, education level, perceived health status and social capital. But social capital that connected with religion and ethnic don't have significant effect on happiness. All predictors are robust. Demographic characteristics inform that married people, non household head, live in urban area, outside of Jawa-Bali islands and Javanese were happier than others. There is no difference in happiness level between man and woman. Happiness-age relationship indicated $U$-shaped curve. Marginal effect shows different effect for every happiness level due to a unit change in independent variable.
\end{abstract}

Keywords: happiness, oprobit, demographic chracteristics

\begin{abstract}
ABSTRAK
Tujuan penelitian ini adalah untuk menganalisis faktor-faktor penentu kebahagiaan di Indonesia. Dengan menggunakan data antar ruang/silang tempat dari Indonesia Family Life Survey (IFLS) wave 4, 2007, studi ini mengambil 17,650 pengamatan yang diestimasi menggunakan model Oprobit. Model Oprobit dipilih karena adanya variabel respon ordinal dan asumsi normal dalam distribusi kesalahan. Hasil penelitian menunjukkan bahwa kebahagiaan di Indonesia secara positif dipengaruhi oleh pendapatan, tingkat pendidikan, status kesehatan yang dirasakan dan modal sosial. Namun demikian, modal sosial yang berkaitan dengan agama dan etnis tidak memiliki pengaruh yang signifikan terhadap kebahagiaan. Semua prediktor bersifat robust. Karakteristik demografi menginformasikan bahwa orang yang menikah, bukan kepala rumah tangga, tinggal di daerah perkotaan, berada di luar pulau Jawa-Bali dan dari suku Jawa lebih bahagia daripada yang lain. Riset ini juga menemukan bahwa tidak terdapat perbedaan dalam tingkat kebahagiaan antara pria dan wanita. Kemudian, hubungan antara kebahagiaan dan usia menunjukkan kurva yang berbentuk U. Terakhir, efek marjinal menunjukkan efek yang berbeda untuk setiap tingkat kebahagiaan karena perubahan unit variabel independen.
\end{abstract}

Kata kunci: kebahagiaan, oprobit, karakteristik demografi 


\section{PENDAHULUAN}

Sejak diperkenalkan pertama kali pada Konferensi Bretton Woods di tahun 1944, Gross Domestic Products (GDP) berperan sebagai ukuran kemajuan ekonomi dan sejak 1960an GDP digunakan sebagai indikator kesejahteraan secara umum. GDP memiliki beberapa kelemahan (Bergh 2009) antara lain tidak memperhitungkan biaya sosial seperti biaya eksternalitas, mementingkan peningkatan pendapatan absolut, mengabaikan distribusi pendapatan, tidak mengukur aktivitas di luar pasar atau transaksi informal dan mengabaikan dampak aktivitas ekonomi terhadap lingkungan hidup. Fleurbaey (2009) mengungkapkan bahwa GDP sebagai pengukur aktivitas ekonomi mengabaikan variasi kekayaan (wealth), jasa produksi rumah tangga, kerusakan lingkungan alam, kualitas relasi sosial, keamanan ekonomi dan keselamatan personal dan harapan hidup.

Berbagai kelemahan tersebut mendorong kebutuhan ukuran alternatif yang lebih dari GDP atau "Beyond GDP" maka sejak tahun 1970an muncul berbagai ukuran alternatif antara lain Measure of Economic Welfare (MEW) oleh Nordhaus dan Tobin, Physical Quality of Life Index (PQLI) oleh Morris pada tahun 1970an, Index of Sustainable Economic Welfare (ISEW) (Daly et al., 1989), Human Development Index (HDI) di tahun 1990an, The Genuine Progress Indicator (GPI) serta The Index of Economic Well-Being (IEWB) (Osberg \& Sharpe 1998). HDI digunakan di seluruh dunia namun masih memiliki kekurangan sehingga muncul Inequality-adjusted Human Development Index (IHDI) pada tahun 2010.

Sejak Konferensi Beyond GDP oleh Komisi Eropa pada November 2007, muncul berbagai ukuran alternatif untuk melakukan koreksi terhadap GDP yaitu Index of Sustainable Welfare, The Genuine Progress Indicator, Green GDP, Genuine Wealth (Costanza et al., 2009) serta Index of Social Progress. Ukuran yang memasukkan indikator psikologi adalah happiness indicators, Gallup-Healthways Well-being Index dan Happy Life Years Index. Ukuran pelengkap GDP adalah Millenium Development Goals (MDGs) dan Sustainable Development Indicators. Berbagai ukuran tersebut belum banyak digunakan kecuali MDGs.

Satu indeks kesejahteraan yang saat ini sedang menjadi perhatian pengambil kebijakan adalah ini adalah indeks kebahagiaan (happiness index). Pada tahun 2011, Sidang Umum Perserikatan Bangsa-bangsa (PBB) mengawali penggunaan indeks ini dan kemudian meluas ke Inggris, Perancis, Australia, Malaysia dan Thailand. Berdasarkan laporan World Happiness Report di antara beberapa negara ASEAN posisi Indonesia terlihat dalam Tabel 1. 
Tabel 1

Posisi Indonesia dalam World Happiness Report

\begin{tabular}{lcc}
\hline \multicolumn{1}{c}{ Negara ASEAN } & $\mathbf{2 0 1 3}$ & $\mathbf{2 0 1 5}$ \\
\hline Singapura & 30 & 24 \\
Thailand & 36 & 34 \\
Malaysia & 56 & 61 \\
Vietnam & 63 & 75 \\
Indonesia & 76 & 74 \\
Philipina & 92 & 90 \\
\hline
\end{tabular}

Sumber :World Happiness Report

Di regional ASEAN, Singapura merupakan negara dengan posisi tertinggi dalam pemeringkatan kebahagiaan diikuti Thailand, Malaysia, Indonesia dan Philipina. Beberapa prediktor yang dipergunakan dalam menghitung angka rata-rata kebahagiaan di atas adalah Gross Domestic Products per kapita, dukungan sosial, harapan hidup sehat saat lahir, kebebasan membuat pilihan dalam hidup, generosity dan persepsi korupsi. Selama dua kali periode laporan, posisi Indonesia masih berkisar pada posisi 70an dengan tren meningkat seperti halnya negara ASEAN lainnya kecuali Malaysia di antara 156 negara di dunia.

New Economic Foundation (NEF) mempublikasikan Happy Planet Index atas 151 negara di dunia dengan menggunakan indikator harapan hidup, experienced well-being dan ecological footprint. Indeks ini menunjukkan efisiensi dalam penggunaan sumber daya dan tidak secara penuh menggambarkan kesejahteraan dalam suatu negara. Tabel 2 menyajikan posisi Indonesia di antara negara-negara ASEAN

Tabel 2

Posisi Indonesia dalam Happy Planet Index

\begin{tabular}{lccc}
\hline \multicolumn{1}{c}{ Negara ASEAN } & $\mathbf{2 0 0 9}$ & $\mathbf{2 0 1 2}$ & $\mathbf{2 0 1 5}$ \\
\hline Vietnam & 5 & 2 & 2 \\
Indonesia & 16 & 14 & 14 \\
Thailand & 41 & 20 & 20 \\
Philipina & 14 & 24 & 25 \\
Malaysia & 33 & 83 & 84 \\
Singapura & 49 & 90 & 90 \\
\hline
\end{tabular}

Sumber :Happy Planet Index

Pada Tabel 2 terlihat bahwa Vietnam merupakan negara paling efisien dalam penggunaan sumber daya dibandingkan negara ASEAN lainnya. Indonesia menduduki posisi kedua tetapi dengan trend menurun. Thailand adalah negara yang mengalami peningkatan efisiensi, sedangkan Philipina, Malaysia dan Singapura mengalami penurunan efisiensi yang ditandai dengan meningkatnya posisi masing-masing selama beberapa tahun terakhir.

Sementara itu Indonesia saat ini sedang melakukan pengukuran tingkat kebahagiaan dengan metoda survei yang dilakukan oleh Badan Pusat Statistik (BPS). Hasil publikasi BPS tentang indeks kebahagiaan menunjukkan bahwa terjadi peningkatan kebahagiaan orang Indonesia terlihat dari peningkatan indeks 65,11 pada tahun 2013 menjadi 68,28 pada tahun 2014. Indeks kebahagiaan tersebut merupakan indeks komposit 
atas tingkat kepuasan terhadap 10 aspek berikut yaitu kesehatan, pendidikan, pekerjaan, pendapatan rumah tangga, keharmonisan keluarga, ketersediaan waktu luang, hubungan sosial, kondisi rumah dan aset, keadaan lingkungan dan kondisi keamanan.

Studi tentang kebahagiaan yang dikaitkan dengan pendapatan pertama kali dilakukan oleh Easterlin (1974). Penelitian tersebut menemukan adanya paradox of happiness atau income paradox yang dikenal dengan Easterlin Paradox, yaitu peningkatan pendapatan tidak mampu meningkatkan kesejahteraan atau kebahagiaan seseorang. Clark et al. (2008) juga menemukan hal yang sama di Amerika Serikat. Adanya Easterlin paradox menunjukkan ada faktor lain selain pendapatan (material) yang memengaruhi kebahagiaan. Pendapatan absolut bukanlah faktor penting penentu kebahagiaan tetapi pendapatan relatif, perbandingan pendapatan (income comparison) Clark dan Senik (2011) serta income aspirations (Stutzer \& Frey, 2010). Faktor non material yang berperan penting adalah yang menyangkut dimensi sosial dari human wellbeing (Helliwell \& Putnam, 2004). Secara lebih spesifik Bartolini dan Bilancini (2010) berpendapat bahwa faktor kualitas dan kuantitas relasi sosial adalah faktor penting yang menjelaskan pertumbuhan subjective well-being. Sejalan dengan hal tersebut, kohesi sosial adalah faktor penting dalam kepuasan hidup seseorang (Berger-Schmitt 2002).

Studi kebahagiaan di Indonesia masih memiliki potensi untuk diteliti. Riset terdahulu sudah dilakukan oleh Landiyanto et al. (2011) dan Sohn (2010). Penelitian ini menekankan pada pentingnya faktor material (pendapatan) dan non material bagi kebahagiaan di Indonesia. Pendapatan berperan penting dalam kesejahteraan di negara berkembang. Ketika kebutuhan pokok telah terpenuhi dan kekayaan makin meningkat, maka perbedaan kesejahteraan atau kebahagiaan individu sangat dipengaruhi oleh faktor non material seperti relasi sosial (Diener \& Seligman, 2004; Kesebir \& Diener, 2008). Ini sejalan dengan teori hirarki kebutuhan Maslow bahwa yang terendah adalah kebutuhan dasar dan ketika pendapatan makin tinggi maka individu akan mencoba memenuhi kebutuhan yang lebih tinggi yaitu kebutuhan sosial, esteem dan aktualiasasi diri (Sirgy 1986).

Studi ini meneliti bagaimana pengaruh pendapatan per kapita, persepsi status kesehatan, pendidikan dan modal sosial terhadap tingkat kebahagiaan orang Indonesia. Variabel demografi yang digunakan adalah umur, jenis kelamin, status perkawinan, posisi dalam keluarga, lokasi tempat tinggal apakah di perkotaan atau perdesaan, di pulau Jawa dan Bali atau di luar kedua pulau tersebut serta suku. Sebagai salah variabel demografi, variabel suku dipilih karena Indonesia memiliki keragaman suku yang luar biasa yaitu sejumlah 1.340 suku (BPS). Norma, nilai, tradisi dan budaya yang dianut tiap suku berbeda sehingga menciptakan kearifan lokal masing-masing. Pemahaman atas pengaruh kearifan lokal setiap suku dalam mempersepsikan kebahagiaan masing-masing orang adalah penting untuk diketahui. Atau apakah terdapat perbedaan kebahagiaan yang dirasakan tiap orang terkait label kesukuan yang dimilikinya. Pertanyaan penelitian yang diajukan adalah bagaimana pengaruh pendapatan absolut,kesehatan, pendidikan dan modal sosial terhadap kebahagiaan di Indonesia. 
Hasil penelitian ini diharapkan dapat memberikan manfaat bagi pengembangan studi kebahagiaan di Indonesia serta perumusan kebijakan pembangunan oleh pemerintah. Dengan demikian kebijakan yang dirumuskan pemerintah merupakan kebijakan yang tepat dan bermuara pada tujuan akhir yaitu meningkatkan kebahagiaan masyarakat.

\section{KAJIAN PUSTAKA DAN PERUMUSAN HIPOTESIS}

\section{Definisi Kebahagiaan}

Kebahagiaan tidak memiliki definisi yang berlaku secara umum. Menurut sosiologi, kebahagiaan tidak berbeda dengan life satisfaction (Veenhoven 1988). Dalam Veenhoven dirumuskan definisi kebahagiaan sebagai "over all appreciation of one's life as a whole." Definisi ini sesuai dengan definisi Jeremy Bentham tentang kebahagiaan yaitu "the sum of pleasure and pains." Dalam hal ini kebahagiaan bermakna sama dengan life satisfaction dan subjective well-being. Veenhoven menambahkan dua komponen kebahagiaan yaitu afektif dan kognitif. Life satisfaction adalah tingkat seseorang dalam menilai seluruh kualitas hidupnya sebagai suatu hal yang positif atau menyenangkan. Dalam Psikologi kebahagiaan tidak sama dengan life satisfaction. Psikologi menggunakan konsep subjective well-being yaitu suatu keadaan well-being secara umum dalam durasi yang panjang meliputi komponen afektif dan kognitif. Subjective well-being terdiri dari happiness dan life satisfaction. Subjective well-being memiliki sinonim dengan being happy sedangkan happiness memiliki sinonim dengan feeling happy. Kahneman (1999) menyatakan bahwa well-being terdiri dari pleasure atau happiness. Well-being dan hedonisme adalah ekuivalen sehingga aliran yang menganut paham ini disebut sebagai aliran hedonis.

Pada umumnya ahli ekonomi tidak terlalu detail untuk mendefinisikan kebahagiaan. Bagi ilmu ekonomi kebahagiaan adalah sesuatu yang sulit didefinisikan tetapi dapat diukur. Oleh karena itu kebahagiaan tidak definisi secara spesifik. Ng (1997) mendefinisikan kebahagiaan sebagai welfare. Clark dan Oswald (1994) mendefinisikan kebahagiaan sebagai pleasure atau satisfaction. Easterlin (1995) tidak membedakan definisi dan arti kebahagiaan dengan subjective well-being, satisfaction, utility, wellbeing, welfare. Frey dan Stutzer (2002) mendefinisikan kebahagiaan sebagai subjective well-being yang dapat digunakan sebagai proksi bagi utilitas.

Dengan demikian, definisi kebahagiaan adalah kesenangan dan ketenteraman hidup lahir batin, keberuntungan, kemujuran yang bersifat lahir batin. Definisi tersebut berasal dari etika dan filsafat yang berkembang dalam masyarakat Indonesia dalam hal ini masyarakat Jawa. Dalam filsafat Suryomentaraman dinyatakan bahwa kebahagiaan adalah kondisi tenteram, nyaman, tidak berkonflik, bebas dari keinginan yang tidak pada tempatnya dan tidak terikat sesuatu. 


\section{Teori Kebahagiaan}

Darin dalam Dutt dan Radcliff (1989) menyatakan bahwa kebahagiaan ditentukan oleh beberapa faktor. Faktor pertama yaitu sifat atau karakter (traits), dimana kebahagiaan adalah sifat atau karakter seseorang yang cenderung tidak berubah, yang berhubungan dengan unsur genetika, budaya dan pengalaman di awal kehidupan seseorang. Individu memiliki suatu tingkat dasar kebahagiaan di mana ia akan selalu menuju ke arah tersebut. Jika ada peristiwa yang memengaruhi tingkat kebahagiaannya maka hal itu hanya akan bersifat sementara karena ia akan segera kembali ke tingkat kebahagiaan semula. Psikolog menyebutnya dengan Set Point Theory. Kedua, perbandingan sosial (Social Comparison), dimana menurut Easterlin (1974) individu menilai kualitas hidupnya tidak secara absolut tetapi secara relatif. Ini berarti ia akan membandingkan hidupnya dengan orang lain. Misalnya ketika pendapatannya meningkat maka hal itu belum tentu akan meningkatkan kabahagiaannya karena ia akan membandingkannya dengan pendapatan orang lain. Ketiga, kebutuhan pokok (Satisfaction Needs), dimana kebahagiaan menurut teori ini ditentukan oleh hubungan dalam keluarga, tingkat kesehatan, pekerjaan dan jumlah uang yang dimiliki yang merupakan kebutuhan pokok bagi manusia.

Veenhoven (1988) membagi teori kebahagiaan menjadi tiga bagian juga yaitu setpoint theory, cognitive theory dan affective theory. Dalam set-point theory, kebahagiaan merupakan sesuatu yang sudah diprogram oleh seseorang dan tidak berkaitan dengan bagaimana hidup seseorang. Kebahagiaan dipengaruhi oleh sifat atau karakter (personal trait), genetika dan budaya. Orang akan berupaya untuk mempertahankan tingkat kebahagiaan yang nyaman baginya (comfortable level). Dalam cognitive theory, kebahagiaan adalah produk dari pemikiran dan refleksi manusia atas perbedaan antara persepsi kehidupan yang sebenarnya dan seharusnya dimiliki. Kebahagiaan tidak dapat dihitung tetapi dapat diketahui. Dalam affective theory, kebahagiaan adalah refleksi manusia tentang seberapa baik kehidupannya secara umum. Jika orang merasa baik di sebagian besar hidupnya maka ia mestinya bahagia.

Seligman (2002) dan Huang (2008) menyatakan ada tiga teori tradisional dan satu teori modern tentang kebahagiaan yaitu hedonism, desire, objective list dan authentic theory. Hedonism theory menyatakan bahwa kebahagiaan berkaitan dengan upaya memaksimalkan pleasure dan meminimalkan pain. Ini merupakan pengalaman perasaan positif oleh individu. Individu yang bahagia akan terlihat sering tersenyum atau mata berbinar-binar. Teori ini merupakan versi modern dari teori utilitarian dari Bentham. Desire theory menyatakan bahwa kebahagiaan berkaitan dengan terpenuhinya keinginan individu. Dikatakan bahwa teori ini lebih baik daripada hedonism. Pemenuhan keinginan akan dapat meningkatkan kebahagiaan seseorang tanpa memandang kesenangan yang dihasilkannya. Menurut objective list theory, kebahagiaan tercapai jika individu mampu memenuhi berbagai tujuan yang diinginkan misalnya pemenuhan kebutuhan materi, kebebasan, kesehatan, pendidikan, pengetahuan, pertemanan. Dalam authentic theory, kebahagiaan terkait dengan tiga hal yaitu pleasant life/pleasure, good life dan meaningful 
of life. Teori menggabungkan tiga teori tradisional sebelumnya yaitu pleasant life terkait dengan hedonism, good life yang terkait dengan pemenuhan keinginan individu dan meaningful life yang terkait dengan objective list.

Biswas-Diener et al. (2004) menyatakan ada tiga penyebab kebahagiaan yaitu karakter seseorang, adaptasi dan relasi sosial. Karakter, terdapat dua karakter dasar seseorang yaitu neuroticism dan extroversion. Karakter neuroticism cenderung mudah marah, rasa bersalah dan depresi. Orang dengan karakter extroversion cenderung mudah merasa senang, antusias meskipun sedang sendiri. Karakter kedua inilah yang mendorong orang lebih berbahagia dibandingkan karakter pertama. Adaptasi, di mana individu memiliki kemampuan beradaptasi terhadap segala kondisi. Makin bagus kemampuan beradaptasi makin besar peluang untuk lebih bahagia. Relasi sosial, dimana dengan memiliki banyak teman, dukungan keluarga, hubungan sosial yang saling percaya dan hubungan yang romantik akan meningkatkan peluang untuk hidup lebih bahagia.

\section{Tinjauan Empiris}

Studi tentang kebahagiaan atau well-being di lingkungan ilmu ekonomi dimulai oleh Richard Easterlin. Risetnya tentang hubungan antara tingkat pendapatan dengan kebahagiaan (1974) menunjukkan adanya easterlin paradox atau happiness paradox. Salah satu penyebab happiness paradox adalah karena happiness dipengaruhi oleh income aspirations (Easterlin 2001). Blanchflower dan Oswald (2004) menyatakan bahwa relative income berperan penting dalam peningkatan happiness. Stevenson dan Wolfers (2008) menemukan fakta empiris bahwa absolute income lebih berperan penting daripada relative income dalam memengaruhi well-being. Clark et al. (2008) menemukan fakta bahwa relative income berperan dalam utility function. Peran relative income juga ditemukan dalam studi empiris yang dilakukan A. Clark dan Senik (2011) di mana income comparison memengaruhi subjective well-being. Ball dan Chernova (2008) menemukan absolute dan relative income berpengaruh positif terhadap happiness namun relative income berperan lebih besar.

Pada umumnya hubungan antara pendidikan dan kebahagiaan tidak dapat dilihat secara langsung. Michalos (2008) menyatakan bahwa untuk melihat hubungan antara pendidikan dengan kebahagiaan tidak dapat dilakukan secara langsung namun tergantung pada definisi dan operasionalisasi pendidikan, pengaruh dan kebahagiaan. Chen (2012) mendapatkan bukti empiris bahwa pendidikan yang dikombinasikan dengan kemampuan menjalin hubungan yang lebih luas akan berdampak positif terhadap well-being. Cuñado dan de Gracia (2012) menemukan dampak langsung dan tidak langsung pendidikan terhadap kebahagiaan. Dampak langsung adalah meningkatkan kepercayaan diri dan kebanggaan serta rasa senang karena mendapatkan pengetahuan. Dampak tidak langsung terlihat dari pengaruh pendidikan terhadap peluang kesempatan kerja yang lebih tinggi, pekerjaan yang lebih baik, gaji yang diharapkan lebih tinggi dan kesehatan yang lebih baik. Blanchflower dan Oswald (1994) menunjukkan bahwa pendidikan meningkatkan kualitas pekerjaan menjadi lebih menarik. 
Hubungan antara kesehatan dengan kebahagiaan masih belum jelas. Di satu sisi kesehatan yang baik akan meningkatkan kebahagiaan. Namun di sisi lain dapat terjadi bahwa orang yang bahagia akan makin tinggi kesehatannya. Selain itu hubungan kesehatan dengan kebahagiaan tidak dapat dipisahkan dari pengaruh variabel lain yang memengaruhi kesehatan. Green dan Elliott (2010) menemukan bahwa orang lebih religius lebih sehat secara mental dan lebih bahagia tanpa memandang keyakinan, aktivitas keagamaan, pekerjaan, keluarga, dukungan sosial dan status finansial. Singer et al. (1999) menemukan bahwa penurunan kualitas kesehatan seiring bertambahnya umur tidak membuat rata-rata kebahagiaan individu berkurang. Hal ini karena ada penyesuaian mental akibat penyakit tersebut sehingga membuat orang menjadi lebih kuat. Penurunan kesehatan fisik dan mental dapat terjadi karena individu ketika orang keluar dari pasar kerja (Dave et al., 2008). Dampak terhadap well-being berbeda untuk orang yang keluar dari pasar kerja secara terpaksa dan sukarela. Mereka yang sukarela keluar dari pasar kerja tidak terlalu terdampak well-being-nya dibanding mereka yang terpaksa keluar dari pasar kerja.

Hubungan modal sosial terhadap kebahagiaan dapat dilihat dari trust yang dibangun antar individu atau masyarakat. Helliwell (2007) menemukan fakta empiris bahwa makin tinggi modal social makin tinggi tingkat trust makin rendah tingkat bunuh diri dan makin tinggi tingkat subjective well-being. Tokuda dan Inoguchi (2008) melakukan studi di Jepang dengan hasil bahwa ada hubungan interpersonal mistrust dengan unhappiness di antara warga Jepang. Helliwell (2006) menemukan fakta empiris bahwa specific dan general trust berdampak positif terhadap subjective well-being melalui saluran ekonomi. Sarracino (2012) dalam risetnya menggunakan proxysocial capital berupa nonmarket relational social capital berupa trust in individual, membership and unpaid voluntary work in various group and organizations dan non relational social capital berupa kepercayaan terhadap institusi pengadilan, agama dan parlemen serta civil service. Hasil risetnya menunjukkan bahwa ada korelasi positif antara berbagai proksi modal sosial dengan kebahagiaan dan life satisfaction. Selain itu ada penurunan kepercayaan dari masyarakat negara-negara maju terhadap institusi pengadilan, agama, parlemen dan civil service. Bertolini et al. (2008) menyimpulkan dari hasil studinya bahwa pada tingkat individu intrinsic relational social capital berhubungan positif dengan kebahagiaan, namun extrinsic relational social capital berhubungan negatif dengan kebahagiaan. Non relational social capital yaitu trust dalam institusi, berhubungan positif dengan kebahagiaan. Prediktor utama dalam kebahagiaan adalah absolute house hold income, reference income dan social capital. House hold income berpengaruh positif terhadap kebahagiaan. Reference income berpengaruh negatif terhadap happiness. Tren dalam modal sosial memprediksi kebahagiaan secara negatif.

Penelitian yang menggunakan data crosssection menghasilkan temuan yang berbeda. Crosssection dalam satu negara ditemukan adanya hubungan positif signifikan antara pendapatan dan kebahagiaan negara maju (Blanchflower dan Oswald 2004; Shields dan Price 2005) dan negara berkembang (Graham dan Pettinato 2002; Lelkes 
2006). Namun korelasi yang rendah ditemukan di United Kingdom (A. E. Clark dan Oswald, 1994) dan di Swiss (Frey dan Stutzer, 2000). Hal yang berbeda ditemukan oleh (Diener et al., 1999) yaitu ada korelasi lebih tinggi antara pendapatan dengan subjective well-being.

\section{METODA PENELITIAN}

\section{Data}

Penelitian ini menggunakan data cross-section IFLS wave IV, 2007. Data Indonesia Family Life Survey (IFLS) merupakan bagian dari survei longitudinal yang diperoleh dari survei terhadap 13.535 rumah tangga di 13 propinsi di Indonesia yaitu Sumatera Utama, Sumatera Barat, Sumatera Selatan, Lampung, DKI Jakarta, Jawa Barat, Jawa Tengah, Yogyakarta, Jawa Timur, Bali, Nusa Tenggara Barat, Kalimantan Selatan dan Sulawesi Selatan.

\section{Variabel Penelitian}

Ukuran tingkat kebahagiaan diambil dari pertanyaan "mempertimbangkan keadaan saat ini, apakah Ibu/Bapak/Saudara merasa bahwa Ibu/Bapak/Saudara sangat bahagia, bahagia, tidak bahagia atau sangat tidak bahagia?“ Terdapat empat alternatif jawaban yang disusun ulang dari tingkat kebahagiaan terendah (1) ke tertinggi (4) yaitu sangat tidak bahagia, tidak bahagia, bahagia, sangat bahagia”. Pendapatan absolut per kapita diproksi dengan pengeluaran per kapita untuk makanan dan non makanan.

Tingkat kesehatan diukur dari persepsi responden terhadap tingkat kesehatannya yang dibedakan menjadi tiga ukuran yaitu kondisi kesehatan secara umum, kondisi kesehatan saat ini dibandingkan setahun yang lalu, kondisi kesehatan saat ini dibandingkan dengan kesehatan orang lain yang seumur. Masing-masing ukuran kesehatan tersebut kemudian dibuat dummy variabel di mana nol untuk kondisi yang tidak baik dan satu untuk kondisi yang baik. Tingkat pendidikan diukur dengan menggunakan pendidikan tertinggi yang dimiliki responden. Setelah itu digolongkan menjadi tiga kelompok pendidikan yaitu pendidikan dasar, menengah pertama, menengah atas dan Tinggi. Dari keempat kelompok tersebut dibuat tiga dummy variabel.

Modal sosial terdiri dari kesediaan membantu warga desa/kelurahan jika dibutuhkan, harus selalu waspada agar tidak dimanfaatkan oleh orang lain, lebih mempercayai sesama suku, bisa menitipkan anak kepada tetangga, bisa menitipkan rumah kepada tetangga, tingkat keamanan desa/kelurahan, keamanan desa/kelurahan untuk berjalan seorang diri di malam hari, lebih percaya pada sesama agama/kepercayaan, adanya penduduk yang berbeda agama/kepercayaan tinggal di desa tersebut, adanya tetangga yang berbeda agama/kepercayaan tinggal di dekat rumah, adanya orang yang berbeda agama/kepercayaan tinggal/kost di rumah, adanya salah satu saudara atau anak menikah beda agama, pembangunan rumah ibadah untuk agama lain di desa tersebut, pentingnya agama yang dianut kandidat dalam menentukan pilihan di pemilu atau pilkada 
serta terakhir adalah pentingnya ketaatan agama kandidat dalam menentukan pilihan di pemilu atau pilkada. Dengan menggunakan analisis faktor, berbagai komponen modal sosial tersebut dikelompokkan dalam lima kelompok yaitu trust etnik dan agama, trust tetangga, rasa aman, rela menolong, toleransi dan pemilu.

\section{Model Empiris}

Penelitian ini mengestimasi model empiris berikut:

$Y_{i}=\alpha+\beta_{1} X_{1 i}+\beta_{2} X_{2 i}+\beta_{3} X_{3 i}+\beta_{4} X_{4 i}+\beta_{5} X_{5 i}+\varepsilon$ 1

Keterangan :

$Y_{i} \quad$ : tingkat kebahagiaan individu

$X_{1 i} \quad$ : logaritma natural dari pendapatan per kapita

$X_{2 i} \quad$ : vektor persepsi kesehatan

$X_{3 i} \quad$ : vektor tingkat pendidikan

$X_{4 i} \quad$ : vektor modal sosial

$X_{5 i} \quad$ : vektor variabel demografi

$\varepsilon \quad$ : error term

\section{Metoda Estimasi}

Riset ini mengunakan model probit salah satu model regresi ordinal yang berasumsi error berdistribusi normal. Model ini dapat diturunkan dari model variabel laten yang bersifat kontinyus dalam rentang hingga . Variabel laten adalah variabel yang nilai sebenarnya tidak diketahui. Variabel laten tersebut diukur secara tidak langsung dengan menggunakan variabel yang terobservasi, . Apabila yang terobervasi merupakan variabel ordinal dan digunakan untuk mendekati nilai variabel laten yang bersifat kontinyus maka model yang digunakan merupakan latent trait model. Model tersebut dikembangkan oleh Anderson (1982, dalam Skrondal dan Rabe-Hesketh 2007). Persamaan berikut menunjukkan bagaimana variabel dependen terobservasi, berhubungan dengan variabel laten .

$y_{i}=m \quad$ if $\tau_{m-1} \leq y_{i}^{*}<\tau_{m} \quad$ untuk $m=1,2, \ldots, J$ 2

Keterangan:

$\tau=$ threshold atau cutpoint yang berjumlah $J-1$

$\tau_{0}=-\infty$

$\tau_{J}=\infty$.

Misalnya ada empat kategori variabel ordinal maka kategori respon yang terobservasi dan terikat pada variabel laten adalah:

$y_{i}=\left\{\begin{array}{l}1=S D \text { if } \tau_{0}=-\infty \leq y_{i}^{*}<\tau_{1} \\ 2=D \text { if } \tau_{1} \leq y_{i}^{*}<\tau_{2} \\ 3=A \text { if } \tau_{2} \leq y_{i}^{*}<\tau_{3} \\ 4=D A \text { if } \tau_{3} \leq y_{i}^{*}<\tau_{4}\end{array}\right.$

Ketika $y^{*}$ melewati suatu cut point maka observed category akan berubah. Model struktural untuk $y^{*}$ terkait dengan variabel penjelas yang terobservasi adalah:

$y_{i}^{*}=X_{i} \beta+\varepsilon_{i}$

Dengan satu variabel penjelas maka model tersebut menjadi: 
$y_{i}^{*}=\alpha+\beta x_{i}+\varepsilon$

Dalam model probit $\operatorname{error}(\varepsilon)$ diasumsikan berdistribusi normal dengan mean $=0$ dan $\operatorname{Var}(\varepsilon)=1$, dan memiliki probability density function (pdf) sebagai berikut:

$\phi(\varepsilon)=\frac{1}{\sqrt{2 \pi}} \exp \left(-\frac{\varepsilon^{2}}{2}\right)$ 6

Serta cumulative density function ( $c d f$ ) sebagai berikut:

$\Phi(\varepsilon)=\int_{-\infty}^{\varepsilon} \frac{1}{\sqrt{2 \pi}} \exp \left(-\frac{t^{2}}{2}\right) d t$ 7

\section{ANALISIS DAN PEMBAHASAN}

\section{Analisis Deskriptif}

Jumlah observasi dalam penelitian ini adalah 17.650 responden. Karakteristik demografi responden adalah 58,90 persen laki-laki, 75,50 persen sudah menikah, 47,56 persen sebagai kepala keluarga, 42,68 persen berlatar belakang etnik Jawa, 52,72 persen tinggal di perkotaan, 50 persen lebih berasal dari Jawa Barat, Jawa Tengah dan Jawa Timur. Dilihat dari tingkat pendidikan diketahui 37 persen responden berpendidikan SD, 14,4 persen SMP, 26 persen setingkat SMA dan hanya 11,84 persen berpendidikan perguruan tinggi. Sebagian besar responden beragama Islam yaitu 89,20 persen dan berumur antara 15-64 tahun dengan rata-rata 35 tahun. Pendapatan per kapita berkisar antara Rp21.740-Rp13.600.000,00 dengan rata-rata sebesar Rp574.248,00. Sebagian besar responden mengatakan dirinya bahagia dengan rincian 85,58 persen bahagia, 6,35 sangat bahagia 7,73 persen tidak bahagia dan hanya 0,34 persen sangat tidak bahagia.

\section{Hasil Estimasi}

Tabel 3 memberikan informasi bahwa variabel bebas yang signifikan berpengaruh terhadap kebahagiaan adalah pendapatan per kapita, tingkat pendidikan, kesehatan dan komponen modal sosial yaitu rela menolong, rasa aman, toleransi dan pentingnya faktor agama dalam pemilu di tingkat daerah. Unsur modal sosial yang tidak signifikan adalah trust terkait etnik dan trust kepada tetangga. Semua variabel penjelas signifikan kecuali wanita. Sedangkan Jawa dan KK signifikan pada significance level $(\alpha) 10$ persen.

Tabel 3

Hasil Estimasi Oprobit

\begin{tabular}{lccc}
\hline \multicolumn{1}{c}{ Variabel Bebas } & Koefisien Regresi & Robust standard error & p-value \\
\hline Lny & 0,188 & 0,018 & 0,000 \\
Umur & $-0,037$ & 0,007 & 0,000 \\
Umur2 & 0,0003 & 0,00008 & 0,000 \\
Wanita & 0,044 & 0,028 & 0,116 \\
Menikah & 0,492 & 0,033 & 0,000 \\
KK & $-0,059$ & 0,030 & 0,073 \\
Jawa & 0,043 & 0,023 & 0,061 \\
Kota & 0,061 & 0,023 & 0,009 \\
Jawa Bali & $-0,079$ & 0,024 & 0,001 \\
Smp & 0,069 & 0,031 & 0,027
\end{tabular}




\begin{tabular}{lccc} 
Sma & 0,189 & 0,030 & 0,000 \\
Kuliah & 0,431 & 0,039 & 0,000 \\
Sehat & 0,199 & 0,038 & 0,000 \\
Sehat sekarang & 0,157 & 0,036 & 0,000 \\
Sehat lain & 0,273 & 0,054 & 0,000 \\
Rela menolong & $-0,130$ & 0,035 & 0,001 \\
Trust etnik & $-0,026$ & 0,027 & 0,347 \\
Trust tetangga & 0,022 & 0,022 & 0,171 \\
Rasa aman & $-0,217$ & 0,040 & 0,000 \\
Toleransi & 0,067 & 0,034 & 0,050 \\
Pemilu & $-0,047$ & 0,014 & 0,001 \\
\hline Sumber : Hasi & & &
\end{tabular}

Sumber : Hasil estimasi

Tabel 4 (Lampiran 1) menunjukkan robustness dari variabel penelitian dalam model regresi Oprobit. Semua variabel bebas robust baik dalam signifikansi maupun dalam arah koefisien regresi kecuali variabel wanita yang robust dalam signifikansi namun tidak robust dalam arah koefisien regresi. Dengan demikian dapat dikatakan bahwa semua variabel bebas yang digunakan dalam model ini memiliki robustness.

Tabel 5 (Lampiran 2) menunjukkan marginal effect dari variabel bebas terhadap variabel tidak bebas. Marginal effect tersebut umumnya berbeda untuk tiap tingkat kebahagiaan. Namun demikian terdapat pola dari marginal effect tersebut di mana marginal effect bertanda negatif untuk tingkat kebahagiaan rendah (sangat tidak bahagia dan tidak bahagia) dan bertanda positif untuk tingkat kebahagiaan tinggi (bahagia dan sangat bahagia) dan sebaliknya.

\section{Pembahasan}

Hasil estimasi menunjukkan bahwa determinan kebahagiaan di Indonesia adalah pendapatan per kapita, tingkat pendidikan dan kesehatan serta beberapa komponen modal sosial. Makin tinggi pendapatan per kapita makin tinggi tingkat kebahagiaan. Hasil ini menunjukkan tidak adanya Easterlin paradox dalam perekonomian Indonesia. Temuan ini juga sejalan dengan temuan di banyak negara berkembang di mana pendapatan masih merupakan unsur penting dalam menentukan kebahagiaan.

Kebahagiaan juga dipengaruhi secara positif oleh tingkat pendidikan. Pendidikan yang lebih tinggi membuka peluang lebih besar untuk menjalin relasi atau network yang lebih luas (Chen 2012), sehingga membuka peluang bekerja yang lebih terbuka. Selain itu pendidikan yang lebih tinggi memungkinkan seseorang mendapatkan pekerjaan yang lebih baik sehingga pendapatan yang diterimanya lebih tinggi. Hal tersebut membuat peningkatan kebahagiaan seseorang (Cuñado \& de Gracia 2012). Pendidikan seringkali digunakan sebagai proksi terhadap earnings menurut para ahli ekonomi (Blanchflower \& Oswald, 2004). Makin tinggi pendidikan makin tinggi penerimaan atau pendapatan. Jika pendapatan masih merupakan unsur penting dalam penentuan kebahagiaan, maka makin tinggi pendidikan, makin tinggi pendapatan dan makin tinggi pula kebahagiaan.

Kesehatan berdampak positif terhadap kebahagiaan. Usaha peningkatan kesehatan merupakan upaya yang tak terpisahkan dari peningkatan good life (Michalos et al., 2000). Hubungan antara kesehatan dan kebahagiaan masih belum jelas. Ada 
kemungkinan bahwa terdapat hubungan dua arah di antara keduanya. Orang yang semakin sehat hidupnya akan semakin bahagia. Di sisi lain ada kemungkinan bahwa perasaan bahagia akan meningkatkan kesehatan (Perneger et al., 2004) serta Gerstenblüth dan Rossi (2013). Namun Diener et al. (2004) menyatakan bahwa orang bahagia pasti sehat, tetapi orang sehat belum tentu bahagia. Kesehatan adalah variabel penjelas yang terkuat terhadap life satisfaction (Kennedy et al., 1983). Michalos et al. (2000) merangkum adanya hubungan positif antara subjective wel-being dengan ukuran obyektif dan subyektif atas kesehatan seperti yang ditemukan oleh Campbell et al. (1976) dan (Andrews \& Withey 1976). Demikian juga yang ditemukan oleh Gerstenblüth dan Rossi (2013) bahwa persepsi kesehatan berhubungan positif dengan kebahagiaan.

Hasil riset ini menunjukkan bahwa modal sosial berperan penting dalam kebahagiaan di Indonesia. Sifat rela menolong berperan dalam meningkatkan kebahagiaan. Juga kondisi keamanan di lingkungan tempat tinggal. Makin aman makin besar kenyamanan sehingga makin besar kebahagiaan. Namun demikian pada umumnya orang Indonesia tidak memiliki trust kepada tetangga di mana mereka tidak bisa menitipkan anak dan rumah kepada tetangga. Lagi pula trust yang terkait dengan agama atau keyakinan tidak memengaruhi kebahagiaan sesorang. Ini merupakan indikasi bahwa dalam kehidupan sosial masyarakat faktor agama atau keyakinan bukan sebagai faktor penghambat dalam memberikan kepercayaan kepada orang lain.

Studi ini menunjukkan bahwa sikap toleransi berdampak positif pada kebahagiaan. Hal membuktikan bahwa semboyan Bhinneka Tunggal Ika diamalkan dalam kehidupan bermasyarakat di Indonesia. Dalam semboyan tersebut tersirat pengakuan akan pluralisme dan multikulturalisme dalam masyarakat Indonesia. Pluralisme menekankan keragaman dalam suku, budaya, agama yang memandang bahwa masing-masing hal tersebut memiliki perbedaan. Multikulturalisme menekankan relasi antar unsur yang berbeda tersebut sehingga dari konsep inilah muncul gagasan kesetaraan, toleransi dan saling menghargai satu sama lain (Syaifuddin 2006). Namun demikian dalam pemilihan umum tingkat daerah faktor agama dan religiositas masih menjadi pertimbangan untuk memilih calon kandidat kepala daerah tertentu seperti terlihat dalam hasil penelitian ini.

Karakteristik demografi memberikan informasi bahwa probabilita kebahagiaan lebih besar dimiliki oleh orang yang menikah, bukan kepala keluarga, tinggal di perkotaan, di luar pulau Jawa dan Bali. Sementara itu tidak ada perbedaan kebahagiaan di antara pria dan wanita. Orang menikah cenderung lebih berbahagia karena pernikahan memberikan hubungan interpersonal yang baik antara suami isteri dan adanya dukungan emosional dalam menghadapi berbagai permasalahan dalam kehidupan sehari-hari. Hal ini sesuai dengan protection support hypothesis (Coombs 1991). Selain itu pernikahan memberikan financial support dan improvement health (Stack \& Eshleman, 1998). Dari sudut pandang ilmu ekonomi, pernikahan memberikan keuntungan berupa jaminan finansial atas situasi ekonomi yang tak diharapkan, adanya skala ekonomis dan spesialisasi dalam keluarga yang mampu meningkatkan akumulasi modal manusia 
sehingga pendapatan menjadi lebih besar dibandingkan orang tidak menikah (Stutzer dan Frey 2006).

Seorang kepala keluarga cenderung tidak bahagia. Dalam gender identity hypothesis (Akerlof \& Kranton 2000) dinyatakan bahwa ada suatu self concept yang dimiliki tiap orang mengenai dirinya. Pria tidak seharusnya melakukan pekerjaan rumah dan pria harus mendapatkan penghasilan lebih besar dari wanita. Hal ini membuat pria merasa dirinya wajib bekerja di luar rumah lebih banyak dalam bentuk full-timeworker untuk meningkatkan kepuasannya. Hal ini yang membuat pria sebagai kepala keluarga merasa memiliki kewajiban yang lebih besar sehingga berpengaruh negatif terhadap kebahagiaannya.

Umur dan kebahagiaan memiliki hubungan seperti huruf U. Makin tinggi umur makin rendah kebahagiaan hingga satu titik minimum tertentu setelah itu meningkatnya umur akan meningkatkan kebahagiaan. Studi ini memperkirakan bahwa kebahagiaan terendah berada pada umur sekitar 62 tahun. Hal ini dapat dikaitkan dengan menurunnya self-rated health terutama setelah umur 50 tahun (Schnittker 2005). Munandar (2001) menyatakan bahwa terdapat perubahan dalam kehidupan psikologis di usia lanjut. Sebagai contoh misalnya perasaan tersisih, tak dibutuhkan lagi, ketidakikhlasan menerima kenyataan baru misalnya karena penyakit yang tak kunjung sembuh atau kematian pasangan hidup. Hal tersebut dapat menyebabkan orang merasa tidak bahagia dalam masa tuanya. Di sisi lain peningkatan kebahagiaan juga dapat terjadi seiring dengan peningkatan umur. Usia lanjut dapat dihubungkan dengan kematangan emosi sehingga lebih mampu beradaptasi bereaksi tepat sesuai dengan tuntutan yang dihadapinya (Hurlock 1959).

Marginal effect menunjukkan dampak setiap perubahan satu unit variabel bebas terhadap satu unit probabilita variabel tidak bebas untuk setiap tingkat kebahagiaan. Dari tanda yang melekat pada koefisien dapat diketahui bahwa peningkatan pendapatan per kapita, persepsi kesehatan dan pendidikan akan menurunkan probabilitas sangat tidak bahagia dan tidak bahagia, namun meningkatkan probabilitas bahagia dan sangat bahagia kecuali pendidikan tinggi yang hanya mampu meningkatkan probabilitas sangat bahagia. Untuk komponen modal sosial diketahui berbagai hasil sebagai berikut. Makin rela menolong, makin kecil probabilitas sangat tidak bahagia dan tidak bahagia, namun makin besar probabilitas bahagia dan sangat bahagia. Makin tidak menaruh trust kepada sesama etnik, agama makin tinggi probabilitas sangat tidak bahagia dan tidak bahagia namun makin rendah probabilitas bahagia dan sangat bahagia. Makin tidak menaruh trust kepada tetangga makin rendah probabilitas sangat tidak bahagia dan tidak bahagia namun makin besar probabilita bahagia dan sangat bahagia. Makin tidak aman suatu wilayah makin besar probabilitas sangat tidak bahagia dan tidak bahagia namun makin rendah probabilitas bahagia dan sangat bahagia. Makin tinggi toleransi makin rendah probabilitas sangat tidak bahagia dan tidak bahagia namun makin tinggi probabilitas bahagia dan sangat bahagia. Makin tidak penting faktor agama dalam pemilu makin besar probabilitas 
sangat tidak bahagia dan tidak bahagia namun makin kecil probabilitas bahagia dan sangat bahagia.

\section{SIMPULAN, KETERBATASAN DAN SARAN}

Studi ini memberikan temuan empiris bahwa determinan kebahagian di Indonesia adalah pendapatan, pendidikan, kesehatan dan modal sosial. Ini juga memberikan indikasi bahwa di Indonesia tidak terdapat Easterlin paradox. Tinggi pendidikan yang semakin tinggi akan menunjukkan kebahagiaan yang semakin tinggi pula. Tingkat pendidikan yang paling besar pengaruhnya pada kebahagiaan adalah ketika seseorang memiliki pendidikan tinggi. Semakin merasa sehat seseorang semakin besar kebahagiaannya. Unsur kesehatan yang paling besar pengaruhnya pada kebahagiaan adalah kesehatan yang dibandingkan dengan orang lain dalam usia yang sama. Unsur modal sosial yang paling besar pengaruhnya adalah rasa aman suatu wilayah. Unsur trust kepada tetangga dan kepada sesama etnik, agama tidak signifikan berpengaruh pada kebahagiaan. Karakteristik demografi menunjukkan bahwa orang yang menikah, bukan kepala keluarga, tinggal di perkotaan, di luar pulau Jawa dan Bali serta berlatar belakang suku Jawa memiliki kecenderungan lebih berbahagia. Sementara itu tidak ada perbedaan kebahagiaan bagi pria dan wanita. Hubungan kebahagiaan dan umur diindikasikan berbentuk huruf $U$.

Dari marginal effect diketahui bahwa peningkatan pendapatan, pendidikan dan kesehatan akan meningkatkan probabilitas sangat bahagia dan bahagia namun menurunkan probabilitas sangat tidak bahagia dan tidak bahagia. Pada umumnya makin rela menolong, bertoleransi, makin aman suatu wilayah akan makin besar probabilitas sangat bahagia dan bahagia namun makin kecil probabilitas sangat tidak bahagia dan tidak bahagia. Semakin rendah trust kepada sesama etnik, agama maka semakin makin besar probabilitas sangat tidak bahagia dan tidak bahagia, namun semakin kecil probabilitas sangat bahagia dan bahagia. Semakin rendah trust kepada tetangga, makin rendah probabilitas sangat tidak bahagia dan tidak bahagia namun makin tinggi probabilita sangat bahagia dan bahagia.

Penelitian ini memiliki keterbatasan terkait ketersediaan data penelitian. Oleh karenanya untuk studi selanjutnya dianjurkan untuk menggunakan data yang lebih lengkap dan komprehensif.

\section{DAFTAR PUSTAKA}

Akerlof, George A., dan Rachel E. Kranton. 2000. "Economics and identity." Quarterly $\begin{array}{lllll}\text { Journal of } & \text { Economics } & 115 & \text { (3): } & 715-53 .\end{array}$ https://doi.org/10.1162/003355300554881.

Andrews, Frank M., dan Stephen Bassett Withey. 1976. Social indicators of well-being American perceptions of life quality. New York: Plenum Press. 
Bartolini, Stefano, dan Ennio Bilancini. 2010. "If not only GDP, what else? Using relational goods to predict the trends of subjective well-being." International Review of Economics 57 (2): 199-213. https://doi.org/10.1007/s12232-010-00981.

Berger-Schmitt, Regina. 2002. "Considering social cohesion in quality of life assessments: Concept and measurement." Social Indicators Research 58 (1-3): 403-28. https://doi.org/10.1023/A:1015752320935.

Bergh, Jeroen C.J.M.van den. 2009. "The GDP paradox." Journal of Economic Psychology 30 (2): 117-35. https://doi.org/10.1016/j.joep.2008.12.001.

Biswas-Diener, Robert, Ed Diener, dan Maya Tamir. 2004. "The psychology of subjective well-being." $\quad$ Daedalus $133 \quad$ (2): $18-25$. https://doi.org/10.1162/001152604323049352.

Blanchflower, David G., dan Andrew J. Oswald. 1994. "Estimating a wage curve for Britain." The Economic Journal 104 (426): 1025-43.

. 2004. "Well-being over time in Britain and the USA." Journal of Public Economics 88 (7-8): 1359-86. https://doi.org/10.1016/S0047-2727(02)00168-8.

Campbell, Angus, Philip E. Converse, dan Willard L. Rodgers. 1976. The quality of american life, perceptions, evaluations, and satisfactions. New York: Rusell Sage Foundation.

Chen, Wan chi. 2012. "How Education Enhances Happiness: Comparison of Mediating Factors in Four East Asian Countries." Social Indicators Research 106 (1): 11731. https://doi.org/10.1007/s11205-011-9798-5.

Clark, Andrew E., dan Andrew J. Oswald. 1994. "Unhappiness and unemployment." The Economic Journal 104 (424): 648-59. https://doi.org/10.2307/2234639.

Clark, Andrew E, Paul Frijters, dan Michael A Shields. 2008. "Relative income, happiness, and utility: An explanation for the easterlin paradox and other puzzles." Journal of Economic Literature 46 (1): 95-144. https://doi.org/10.1257/jel.46.1.95.

Clark, Andrew, dan Claudia Senik. 2011a. "Will GDP growth increase happiness in developing countries?"

- 2011b. "Will GDP growth increase happiness in developing countries? The institute for the study of labor (IZA)." 5595.

Coombs, Robert H. 1991. "Marital Status and Personal Well-Being: A Literature Review.” Family Relations 40 (1): 97. https://doi.org/10.2307/585665.

Costanza, Robert, Maureen Hart, Stephen Posner, dan John Talberth. 2009. "Beyond GDP : The need for new measures of progress." Boston University, no. 4: 1-47. https://doi.org/0109 970401. 
Cuñado, Juncal, dan Fernando Pérez de Gracia. 2012. "Does Education Affect Happiness? Evidence for Spain.” Social Indicators Research 108 (1): 185-96. https://doi.org/10.1007/s11205-011-9874-x.

Daly, Herman E., John B. Cobb, dan Clifford W. Cobb. 1989. For the common good: Redirecting the economy toward community, the environment, and a sustainable future. 4ed. Boston: Beacon Press.

Dave, Dhaval, Inas Rashad, dan Jasmina Spasojevic. 2008. “The effects of retirement on physical and mental health outcomes." Southern Economic Journal 75 (2): 497523. https://doi.org/10.2139/ssrn.1024475.

Diener, Ed, dan Martin E.P. Seligman. 2004. "Beyond money: Toward an economy of well-being." Psychological Science in the Public Interest 5 (1): 1-31. https://doi.org/10.1111/j.0963-7214.2004.00501001.x.

Diener, Ed, Eunkook M. Suh, Richard E. Lucas, dan Heidi L. Smith. 1999. "Subjective well-being: Three decades of progress." Psychological Bulletin 125 (2): 276-302. https://doi.org/10.1037/0033-2909.125.2.276.

Dutt, Amitava Krishna, dan Benjamin Radcliff. 1989. "Happiness, economics and politics: Towards multi-disciplinary approach.” Edward Elgar Publishing, 1989.

Easterlin, Richard A. 1974. "Does economic growth improve the human lot? In nations and households in economic growth: Essays in honor of moses abramovitz." Academic Press, 89-125.

Easterlin, Richard A. 1995. "Will raising the incomes of all increase the happiness of all?" Journal of Economic Behavior and Organization 27 (1): 35-47. https://doi.org/10.1016/0167-2681(95)00003-B.

- 2001. "Income and happiness: Towards a unified theory." Economic Journal 111 (473): 465-84. https://doi.org/10.1111/1468-0297.00646.

Fleurbaey, Marc. 2009. "Beyond GDP: The quest for a measure of social welfare." Journal of Economic Literature $47 \quad$ (4): $1029-75$. https://doi.org/10.1257/jel.47.4.1029.

Frey, Bruno S., dan Alois Stutzer. 2000. "Happiness, economy and institutions." The Economic Journal 110 (466): 918-38. https://doi.org/10.1111/1468-0297.00570.

. 2002. "What can economists learn from happiness research?" Journal of Economic Literature 40 (2): 402-35.

Gerstenblüth, Mariana, dan Máximo Rossi. 2013. “Are healthier people happier? Evidence from Chile and Uruguay." Development in Practice 23 (2): 205-16. https://doi.org/10.1080/09614524.2013.772024.

Graham, Carol, dan Stefano Pettinato. 2002. Happiness and hardship: Opportunity and insecurity in new market economies. Foreign Affairs. Vol. 81. Washington D.C.: 
The Brookings Institute. https://doi.org/10.2307/20033289.

Green, Morgan, dan Marta Elliott. 2010. "Religion, health, and psychological wellbeing." Journal of Religion and Health 49 (2): 149-63. https://doi.org/10.1007/s10943-009-9242-1.

Helliwell, John F. 2006. “Well-being, social capital and public policy: What's new?” The Economic Journal 116 (510): 34-45. https://doi.org/10.1111/j.14680297.2006.01074.x.

2007. "Well-Being and Social Capital: Does Suicide Pose a Puzzle?" Social Indicators Research 81 (3): 455-96. https://doi.org/10.1007/s11205-006-0022-y.

Helliwell, John F., dan Robert D. Putnam. 2004. “The social context of well-being.” In Philosophical Transactions of the Royal Society B: Biological Sciences, 1435-46. https://doi.org/10.1098/rstb.2004.1522.

Huang, Peter H. 2008. "Authentic happiness, self-knowledge and legal policy." J.L.SCI \& TECH 9 (2): 755-84.

Hurlock, E. B. 1959. Developmental Psychology. New York: McGraw Hill.

Kahneman, D. 1999. “Objective happiness. In D. Kahneman, E. Diener, \& N. Schwarz (Eds.), Well-being: The foundations of hedonic psychology." New York: Russell Sage Foundation. New York.

Kennedy, Catherine A., James A. King, dan William A. Muraco. 1983. "The relative strength of health as a predictor of life satisfaction." International Social Science Review 58 (2): 97-102.

Kesebir, Pelin, dan Ed Diener. 2008. "In pursuit of happiness: Empirical answers to philosophical questions.” Perspectives on Psychological Science 3 (2): 117-25. https://doi.org/10.1111/j.1745-6916.2008.00069.x.

Landiyanto, Erlangga Agustino, Jeffrey Ling, Mega Puspitasari, dan Septi Eka Irianti. 2011. "Wealth and happiness: Empirical evidence from Indonesia." Chulalongkron Journal of Economics 23: 1-17.

Lelkes, Orsolya. 2006. "Tasting freedom: Happiness, religion and economic transition." Journal of Economic Behavior and Organization 59 (2): 173-1. https://doi.org/10.1016/j.jebo.2004.03.016.

Michalos, Alex C. 2008. "Education, happiness and wellbeing." Social Indicators Research 87 (3): 347-66. https://doi.org/10.1007/s11205-007-9144-0.

Michalos, Alex C., Bruno D. Zumbo, dan Anita Hubley. 2000. "Health and the quality of life." Social Indicators Research 51 (3): 245-86.

Munandar, Utami. 2001. Bunga rampai psikologi perkembangan dari bayi sampai dengan lanjut usia. Jakarta: Universitas Indonesia Press. 
Ng, Yew-Kwang. 1997. "A case for happiness, cardinalism, and interpersonal comparability." Economic Journal $107 \quad$ (445): 1848-58. https://doi.org/10.1111/j.1468-0297.1997.tb00087.x.

Perneger, Thomas V., Patricia M. Hudelson, dan Patrick A. Bovier. 2004. "Health and happiness in young Swiss adults." Social Indicators Research 51 (3): 245-86. https://doi.org/10.1023/B:QURE.0000015314.97546.60.

Sarracino, Francesco. 2012. "Money, sociability and happiness: Are developed countries doomed to social erosion and unhappiness?: Time-series analysis of social capital and subjective well-being in Western Europe, Australia, Canada and Japan." Social Indicators Research 109 (2): 135-88. https://doi.org/10.1007/s11205-0119898-2.

Schnittker, Jason. 2005. "When mental health becomes health: Age and the shifting meaning of self-evaluations of general health." Milbank Quarterly 83 (3): 397423. https://doi.org/10.1111/j.1468-0009.2005.00407.x.

Seligman, Martin E. P. 2002. Authentic happiness: Using the new positive psychology to realize your potential for lasting fulfillment. New York: Free Press.

Shields, Michael A., dan Stephen Wheatley Price. 2005. "Exploring the economic and social determinants of psychological well-being and perceived social support in England." Journal of the Royal Statistical Society. Series A: Statistics in Society 168 (3): 513-37. https://doi.org/10.1111/j.1467-985X.2005.00361.x.

Singer, M A, W M Hopman, dan T A MacKenzie. 1999. "Physical functioning and mental health in patients with chronic medical conditions." Quality of life research : an international journal of quality of life aspects of treatment, care and rehabilitation 8 (8): 687-91.

Sirgy, M. Joseph. 1986. “A quality-of-life theory derived from maslow's developmental perspective." American Journal of Economics and Sociology 45 (3): 329-42. https://doi.org/10.1111/j.1536-7150.1986.tb02394.x.

Sohn, Kitae. 2010. "Considering happiness for economic development: determinants of happiness in Indonesia." KIEP Research Paper No. Working Papers-10-09 10 (9): $1-61$.

Stack, Steven, dan J. Ross Eshleman. 1998. "Marital Status and Happiness: A 17-Nation Study." Journal of Marriage and the Family 60 (2): 527-36. https://doi.org/10.2307/353867.

Stutzer, Alois, dan Bruno S. Frey. 2006. "Does marriage make people happy, or do happy people get married?" Journal of Socio-Economics 35 (2): 326-47. https://doi.org/10.1016/j.socec.2005.11.043.

Stutzer, Alois, dan Bs Frey. 2010. "Recent advances in the economics of individual subjective well-being." Social Research: An International Quarterly 77 (4850): 
679-714. https://doi.org/10.1353/sor.2010.0055.

Syaifuddin, Achmad Fedyani. 2006. "Membumikan Multikulturalisme di Indonesia." ETNOVIsSI Jurnal Antropologi Sosial Budaya II (1): 3-11.

Tokuda, Yasuharu, dan Takashi Inoguchi. 2008. "Interpersonal mistrust and unhappiness among Japanese people.” Social Indicators Research 89 (2): 349-60. https://doi.org/10.1007/s11205-007-9235-y.

Veenhoven, Ruut. 1988. "The utility of happiness." Social Indicators Research 20 (4): 333-54. https://doi.org/10.1007/BF00302332. 


\section{LAMPIRAN 1}

Tabel 4

Robustness Model Oprobit

\begin{tabular}{|c|c|c|c|c|c|}
\hline \multirow{2}{*}{ Variabel Bebas } & \multicolumn{5}{|c|}{ Koefisien Regresi } \\
\hline & $0,237 * * *$ & $0,255 * * *$ & $0,179 * * *$ & $0,185 * * *$ & $0,188 * * *$ \\
\hline Lny & $(0,016)$ & $(0,017)$ & $(0,018)$ & $(0,018)$ & $(0,018)$ \\
\hline \multirow[t]{2}{*}{ Umur } & & $-0,029 * * *$ & $-0,035 * * *$ & $-0,037 * * *$ & $-0,037 * * *$ \\
\hline & & $(0,006)$ & $(0,006)$ & $(0,006)$ & $(0,007)$ \\
\hline \multirow[t]{2}{*}{ Umur2 } & & $0,002 * * *$ & $0,0003 * * *$ & $0,0003 * * *$ & $0,0003 * * *$ \\
\hline & & $(0,00008)$ & $(0,00008)$ & $(0,00008)$ & $(0,00008)$ \\
\hline \multirow[t]{2}{*}{ Wanita } & & $-0,012$ & 0,009 & 0,025 & 0,044 \\
\hline & & $(0,017)$ & $(0,028)$ & $(0,028)$ & $(0,028)$ \\
\hline \multirow[t]{2}{*}{ Menikah } & & $0,471 * * *$ & $0,481 * * *$ & $0,477 * * *$ & $0,492 * * *$ \\
\hline & & $(0,030)$ & $(0,030)$ & $(0,031)$ & $(0,033)$ \\
\hline \multirow[t]{2}{*}{ KK } & & $-0,077 * * *$ & $-0,058 * *$ & $-0,060 * *$ & $-0,059 *$ \\
\hline & & $(0,029)$ & $(0,029)$ & $(0,029)$ & $(0,030)$ \\
\hline \multirow[t]{2}{*}{ Jawa } & & $0,053 * *$ & $0,054 * *$ & $0,038 *$ & $0,043^{*}$ \\
\hline & & $(0,022)$ & $(0,023)$ & $(0,023)$ & $(0,023)$ \\
\hline \multirow[t]{2}{*}{ Kota } & & $0,101 * * *$ & $0,049 * *$ & $0,052 * *$ & $0,061 * * *$ \\
\hline & & $(0,022)$ & $(0,023)$ & $(0,023)$ & $(0,023)$ \\
\hline \multirow[t]{2}{*}{ Jawa Bali } & & $-0,065 * * *$ & $-0,060 * *$ & $-0,072 * * *$ & $-0,079 * * *$ \\
\hline & & $(0,024)$ & $(0,024)$ & $(0,024)$ & $(0,024)$ \\
\hline \multirow[t]{2}{*}{ Smp } & & & $0,079 * *$ & $0,075 * *$ & $0,069 * *$ \\
\hline & & & $(0,031)$ & $(0,031)$ & $(0,024)$ \\
\hline \multirow[t]{2}{*}{ Sma } & & & $0,199 * * *$ & $0,194 * * *$ & $0,189 * * *$ \\
\hline & & & $(0,029)$ & $(0,030)$ & $(0,030)$ \\
\hline \multirow[t]{2}{*}{ Kuliah } & & & $0,464 * * *$ & $0,450 * * *$ & $0,431 * * *$ \\
\hline & & & $(0,039)$ & $(0,039)$ & $(0,039)$ \\
\hline \multirow[t]{2}{*}{ Sehat } & & & & $0,205 * * *$ & $0,199 * * *$ \\
\hline & & & & $(0,038)$ & $(0,038)$ \\
\hline \multirow[t]{2}{*}{ Sehat sekarang } & & & & $0,152 * * *$ & $0,157 * * *$ \\
\hline & & & & $(0,036)$ & $(0,036)$ \\
\hline \multirow[t]{2}{*}{ Sehat lain } & & & & $0,285 * * *$ & $0,273 * * *$ \\
\hline & & & & $(0,054)$ & $(0,054)$ \\
\hline \multirow[t]{2}{*}{ Rela menolong } & & & & & $-0,130 * * *$ \\
\hline & & & & & $(0,035)$ \\
\hline \multirow[t]{2}{*}{ Trust etnik } & & & & & $-0,026$ \\
\hline & & & & & $(0,027)$ \\
\hline \multirow[t]{2}{*}{ Trust tetangga } & & & & & 0,022 \\
\hline & & & & & $(0,022)$ \\
\hline \multirow[t]{2}{*}{ Rasa aman } & & & & & $-0,217 * * *$ \\
\hline & & & & & $(0,040)$ \\
\hline \multirow[t]{2}{*}{ Toleransi } & & & & & $0,067 *$ \\
\hline & & & & & $(0,034)$ \\
\hline \multirow[t]{2}{*}{ Pemilu } & & & & & $-0,047 * * *$ \\
\hline & & & & & $(0,014)$ \\
\hline
\end{tabular}

Sumber : Hasil estimasi

Angka dalam kurung adalah robust standard error.

*) $\alpha 10 \%, * *$ ) $\alpha 5 \%, * * *) \alpha 1 \%$ 


\section{LAMPIRAN 2}

Tabel 5

Marginal Effect

\begin{tabular}{lcccc}
\hline Variabel Bebas & Sangat Tidak & Tidak Bahagia & Bahagia & $\begin{array}{c}\text { Sangat } \\
\text { Bahagia }\end{array}$ \\
\hline lny & $-0,001$ & $-0,024$ & 0,004 & 0,020 \\
Umur & 0,0002 & 0,005 & $-0,0009$ & $-0,004$ \\
Umur2 & $-1,99 \mathrm{e}-06$ & $-0,00004$ & $7,52 \mathrm{e}-06$ & 0,0003 \\
Wanita & $-0,0003$ & $-0,005$ & 0,001 & 0,005 \\
Menikah & $-0,005$ & $-0,073$ & 0,034 & 0,054 \\
KK & 0,0003 & 0,007 & $-0,001$ & $-0,006$ \\
Jawa & $-0,0003$ & $-0,005$ & 0,001 & 0,005 \\
Kota & $-0,0004$ & $-0,008$ & 0,001 & 0,007 \\
Jawa Bali & 0,0005 & 0,010 & $-0,002$ & $-0,009$ \\
Smp & $-0,0004$ & $-0,008$ & 0,001 & 0,008 \\
Sma & $-0,001$ & $-0,022$ & 0,002 & 0,022 \\
Kuliah & $-0,002$ & $-0,043$ & $-0,015$ & 0,061 \\
Sehat & $-0,002$ & $-0,028$ & 0,010 & 0,019 \\
Sehat sekarang & $-0,001$ & $-0,021$ & 0,007 & 0,015 \\
Sehat lain & $-0,002$ & $-0,040$ & 0,018 & 0,024 \\
Rela menolong & 0,0008 & 0,016 & $-0,003$ & $-0,014$ \\
Trust etnik & 0,0002 & 0,003 & $-0,007$ & $-0,003$ \\
Trust tetangga & $-0,0001$ & $-0,003$ & 0,0005 & 0,002 \\
Rasa aman & 0,001 & 0,027 & $-0,005$ & $-0,023$ \\
Toleransi & $-0,0004$ & $-0,008$ & 0,002 & 0,007 \\
Pemilu & 0,0003 & 0,006 & $-0,001$ & $-0,005$ \\
\hline Sumber : Hail & & &
\end{tabular}

Sumber : Hasil estimasi 